\title{
SMOGANICA - A CAVE DEVELOPED IN UPPER CRETACEOUS BRECCIA
}

\author{
SMOGANICA - JAMA RAZVITA V ZGORNJEKREDNI BREČI \\ MARTIN KNEZ ${ }^{1}$, TADEJ SLABE $^{1} \&$ STANKA ŠEBELA $^{1}$
}

\footnotetext{
${ }^{1}$ Inštitut za raziskovanje krasa ZRC SAZU, Titov trg 2, SI-6230 Postojna, Slovenia, Email:knez@zrc-sazu.si
} 


\section{Martin Knez, Tadej Slabe \& Stanka Šebela: Smoganica - a cave developed in upper Cretaceous breccia}

On the Banjšice plateau (NW Slovenia) the longest spring cave is $492 \mathrm{~m}$ long Smoganica. The cave (505 m above sea level) is situated on the SW slope of Čukla $(770 \mathrm{~m}) \mathrm{E}$ from the Soča river ( $153 \mathrm{~m}$ above the sea level). Smoganica is developed in limestone breccia, which is $10 \mathrm{~m}$ thick and belongs to the Upper Cretaceous flysch rocks. On the territory around the cave, the green marls are included in breccias or breccias are included into the green marls. Clasts in coarse-grained breccia, in which the cave is located, vary from some $\mathrm{cm}$ to several $\mathrm{dm}$ in diameter. Clasts are mostly deriving from younger rudist limestones, Lower and Upper Cretaceous and Jurassic micritic and oolitic limestones. Smoganica is situated about $2 \mathrm{~km}$ south from Idrija fault and about 200 m north from Kobarid fault. There are two principal fissure orientations in the cave, $\mathrm{N} 30-45^{\circ} \mathrm{E}$ and $\mathrm{N} 120-135^{\circ} \mathrm{E}$. Smoganica was formed from the system of smaller passages that have been developed inside the breccia in 3D. The cave was formed in phreatic conditions, later it was completely filled with cave sediments. In the next stage the above-sediment rock forms were developed. Cave sediments were later removed from the cave. Today the active water stream is cutting rock forms in the bottom of the cave passages. Higher water quantities are forming scallops and potholes and lower quantities floor channels. Smoganica can be described as polygenetic cave because the percolating water is reshaping the passages.

Key words: Upper Cretaceous breccia, Smoganica cave, Slovenia.

\section{Izvleček}

UDK: 551.44:551.763.33(497.4)

\section{Martin Knez, Tadej Slabe \& Stanka Šebela: Smoganica - jama razvita v zgornjekredni breči}

Na planoti Banjšice (SZ Slovenija) je najdaljša izvirna jama Smoganica, dolga 492 m. Jama (na nadmorski višini 505 m) leži na jugozahodnem pobočju Čukle $(770$ m) vzhodno od reke Soče (153 m nad morjem). Smoganica se je razvila v apnenčevi breči, ki je tu debela $10 \mathrm{~m}$ in je del zgornjekrednih flišnih plasti. V okolici jame so zeleni laporji kot vključki v breči ali pa je breča vključena v plasti zelenega laporja. Klasti v debelozrnati breči, $\mathrm{v}$ kateri je tudi jama, merijo od nekaj $\mathrm{cm}$ do več $\mathrm{dm} v$ premeru. Klasti večinoma izvirajo iz mlajših rudistnih apnencev, spodnje in zgornje krede ter jurskih mikritnih in oolitnih apnencev. Jama Smoganica leži okrog $2 \mathrm{~km}$ južno od Idrijskega preloma in okrog $200 \mathrm{~m}$ severno od Kobariškega preloma. V jami zasledimo dve glavni razpoklinski smeri: $\mathrm{N} 30-45^{\circ} \mathrm{E}$ in $\mathrm{N} 120-135^{\circ} \mathrm{E}$. Smoganica se je oblikovala kot sistem manjših rovov, ki so se razvili znotraj breče v vseh smereh. Jama je nastala v freatičnih razmerah. Kasneje je bila v celoti zapolnjena s sedimenti, nad katerimi so nastale nadsedimentne skalne oblike. Sedimenti so bili nato iz jame odnešeni. Današnji vodni tok oblikuje dno jamskih rovov. Višje vode oblikujejo fasete in draslje, nižje pa talne žlebove. Jamo lahko opredelimo kot poligenetsko, saj je njene dele že povsem preoblikovala voda, ki prenika s površja in polzi po jamskih stenah.

Ključne besede: zgornjekredna breča, Smoganica, Slovenija. 


\section{INTRODUCTION}

On the Banjšice plateau (NW Slovenia) the longest spring cave is $492 \mathrm{~m}$ long Smoganica (Jama pod Smoganico, cad. number 823). The cave (505 m a.s.l.) is situated on the SW slope E from the Soča river (153 m a.s.l.). Smoganica (Figures 1 and 2) is developed in limestone breccia, which is $10 \mathrm{~m}$ thick and belongs to the Upper Cretaceous flysch rocks.

In the distance of $200 \mathrm{~m}$ the principal passage grows for $16 \mathrm{~m}$, the narrow and smaller passages deeper in the cave are not accessible. The cave has some chimneys and rare flowstone. There are two cave floors. The lower one is today filled with water. According to Habič (1974) higher dry passages are the older ones and partly reshaped by collapses. In both cave floors the erosional and corrosional shapes are still prevailing. Slabe (1995) describes the cave as a polygenetic cave. Janež et al. (1997) stress that the result of the water flow along the fissures in carbonate rock is the branch pattern ground plan of the Smoganica cave.

Similar but smaller spring caves are near Bolterjev Zdenec spring near Avšček, near Ajbca nad Logom near Bodrež and near Mournik close to Draga on Banjšice. All were formed in conglomerates of flysch rocks and are situated relatively high in the steep edges of the Banjšice plateau (Janež et al. 1997).

On the basis of our field studies we determined that the Smoganica cave is developed in carbonate breccia.

In Slovenia mightily prevail karst caves developed in limestone. In a smaller extent there are caves in dolomite, conglomerates and breccias. This is why the origin and development of Smoganica in the Upper Cretaceous breccia within the flysch rocks is so interesting.

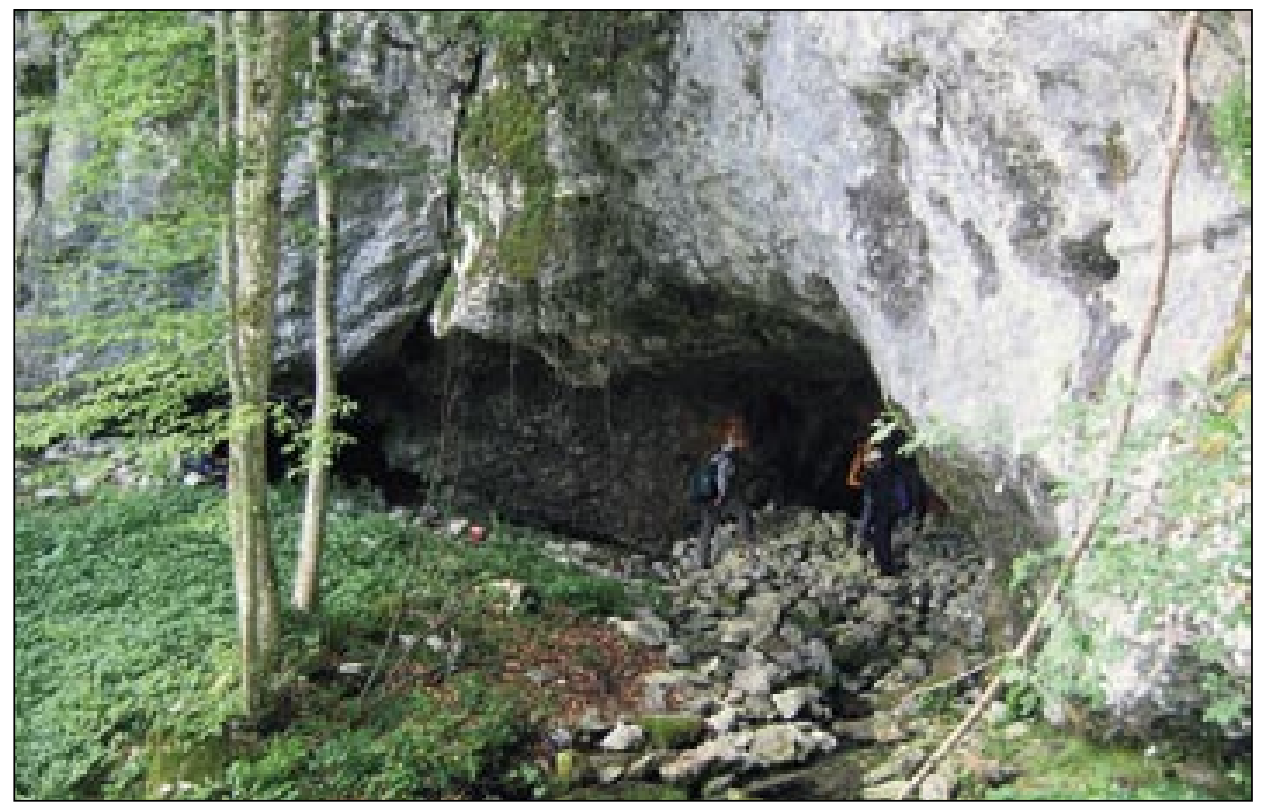

Figure 1: Entrance to Smoganica cave (photo by M. Knez).

Slika 1: Vhod v Smoganico (foto M. Knez). 


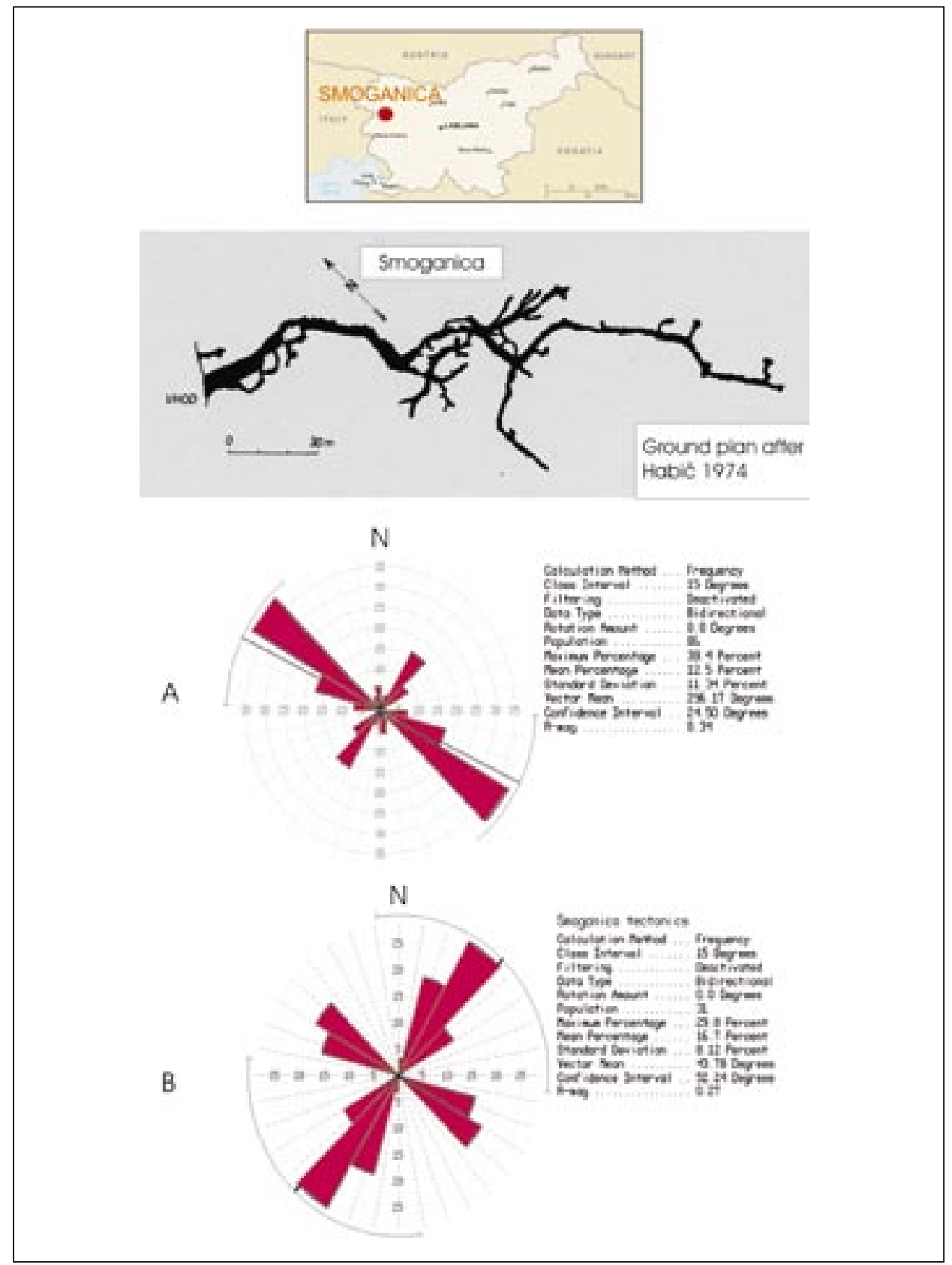

Figure 2: Ground plan of Smoganica with rose diagrams. A-passage orientation, B-fissure orientation.

Slika 2: Tloris Smoganice z diagrami-rozetami. A-smer rovov, B- smer razpok. 


\section{LITHOLOGY AND STRATIGRAPHY}

Flysch rocks with green and reddish marls, sandstones, calcarenites and breccias occupy in Outer Dinarides extensive territory along the Soča river. They are typical example of sediments of proximal, that is, marginal part of flysch basin (Buser 1986).

Wider region of Tolminski Lom is characterized by coarse limestone breccia with marls, hard marls with limestone breccia and flysch with limestone breccia and hard marl, which are of Maastrichtian age (Buser 1987).

Coarse limestone breccia is composed mostly of Creataceous and Jurassic limestones. No Triassic limestone was found in this breccia. Clasts are tightly packed and the weathered breccia surface often gives the appearance of limestone. Cement is mostly crumbled limestone, rarely calcite or marl. When the breccia layers are thicker the cement is carbonate while in thinner beds marl cement prevails. As clasts are tightly packed there is relatively little of cement. Often single limestone pieces float in flysch marl. Below breccia inliers flysch beds are folded due to slipping of solid limestone blocks over not yet consolidated flysch layers. Underwater slides transporting carbonate material to form breccia frequently tore flysch layers from the bottom, rolled and folded them. Thus larger irregular thinly folded flysch inliers are found at some places in breccia. The breccia age was determined mostly by macrofossils such as rudists and corals.

Marl layers are of various thicknesses, from one to several metres. Where the layers are thinner a gradual transition from breccia to marl is seen. In marl there are often pieces of limestone. The marl

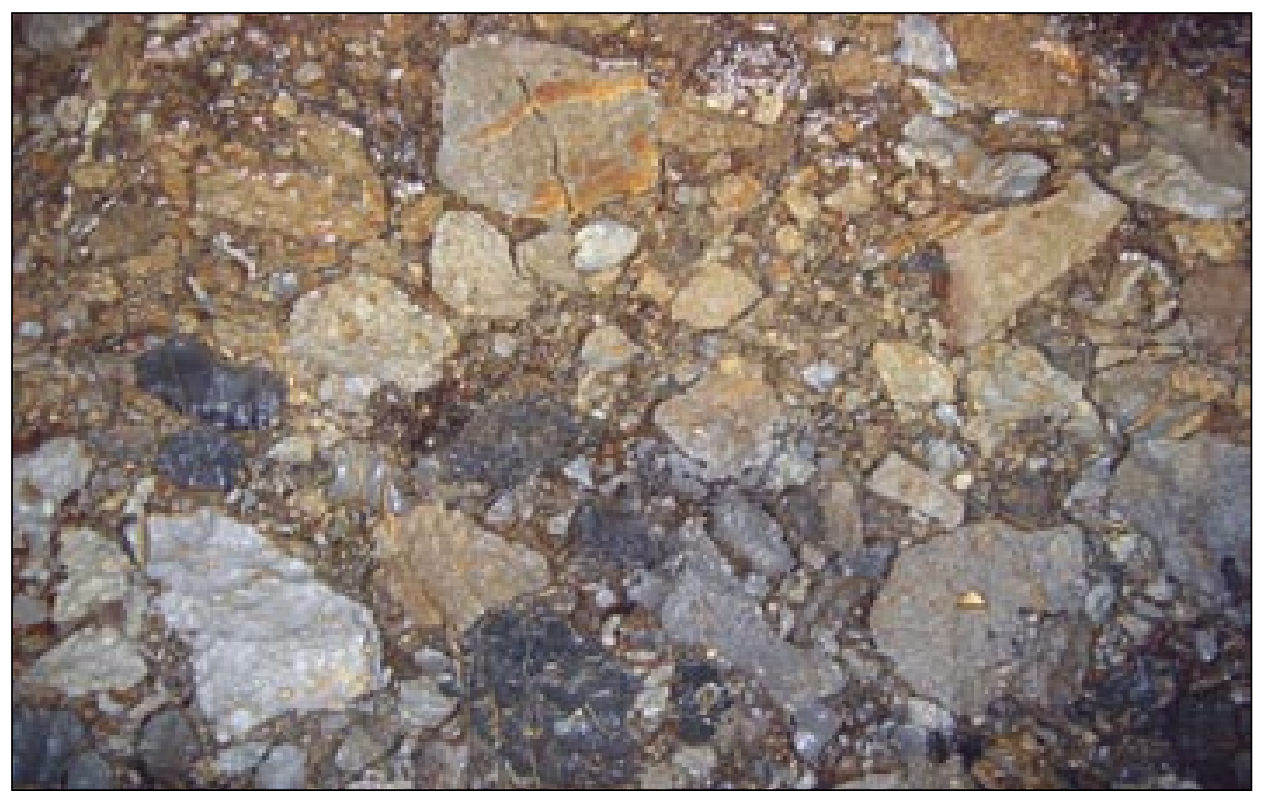

Figure 3: Maastrichtian breccia contains Cretaceous and Jurassic clasts having from some cm to some dm in diameter (Photo by M. Knez).

Slika 3: Maastrichtijsko brečo sestavljajo kredni in jurski klasti, ki merijo v premeru od nekaj cm do nekaj dm (foto M. Knez). 
colour varies from green to red. Essentially marl is the flysch sediment but as there are no layers of sandstone or calcarenite between the layers of marl the Geological map (Buser 1987) treats it as a special variety. Marl is frequently massive. Dip of strata may be determined only when there are thinner beds of sandstone, calcarenite or limestone breccia between marl layers. The age of marl in non-carbonate layers was determined by microfossils, the most common are globotruncans and nannoplancton, at some places also shells.

Where flysch layers contain sandstone beds they are from some $\mathrm{cm}$ to one m thick. Sandstones always contain mica. In layers a gradual granularity, parallel lamination and other may be noticed. There are only few flow traces at the lower side of sandstone layers.

In the region of Tolminski Lom the thickness of breccia, marl and flysch does not exceed $500 \mathrm{~m}$.

On the territory around the cave, the green marls are included in breccias or breccias are included in green marls. Individual lithological members vertically and laterally uninterruptedly pass one into another or their contacts are sharp. Clasts in coarse-grained breccia, in which the cave is located, vary from some $\mathrm{cm}$ to several $\mathrm{dm}$ in diameter. Clasts are deriving mostly from younger rudist limestones, Lower and Upper Cretaceous and Jurassic micritic and oolitic limestones. Sorting of clasts in breccia is not noticed. Breccia is massive and only rarely bedded. Smoganica is developed on the contact between upper limestone breccia and lower nonpermeable green marl. In the vicinity other similar spring caves are developed between breccia and marl. They are situated high on the steep slopes of Banjšice plateau.

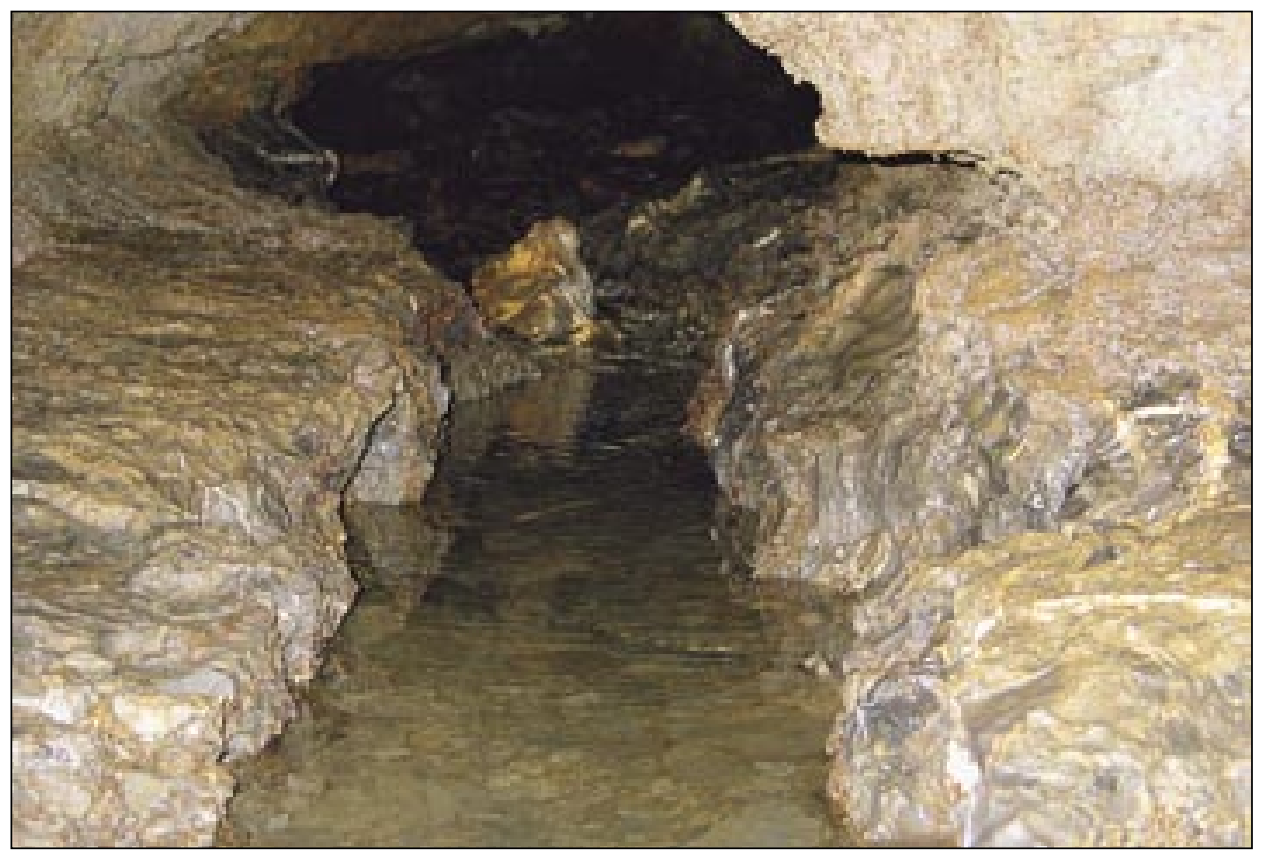

Figure 4: Passage developed in breccia (photo by T. Slabe).

Slika 4: Rov razvit v breči (foto T. Slabe). 

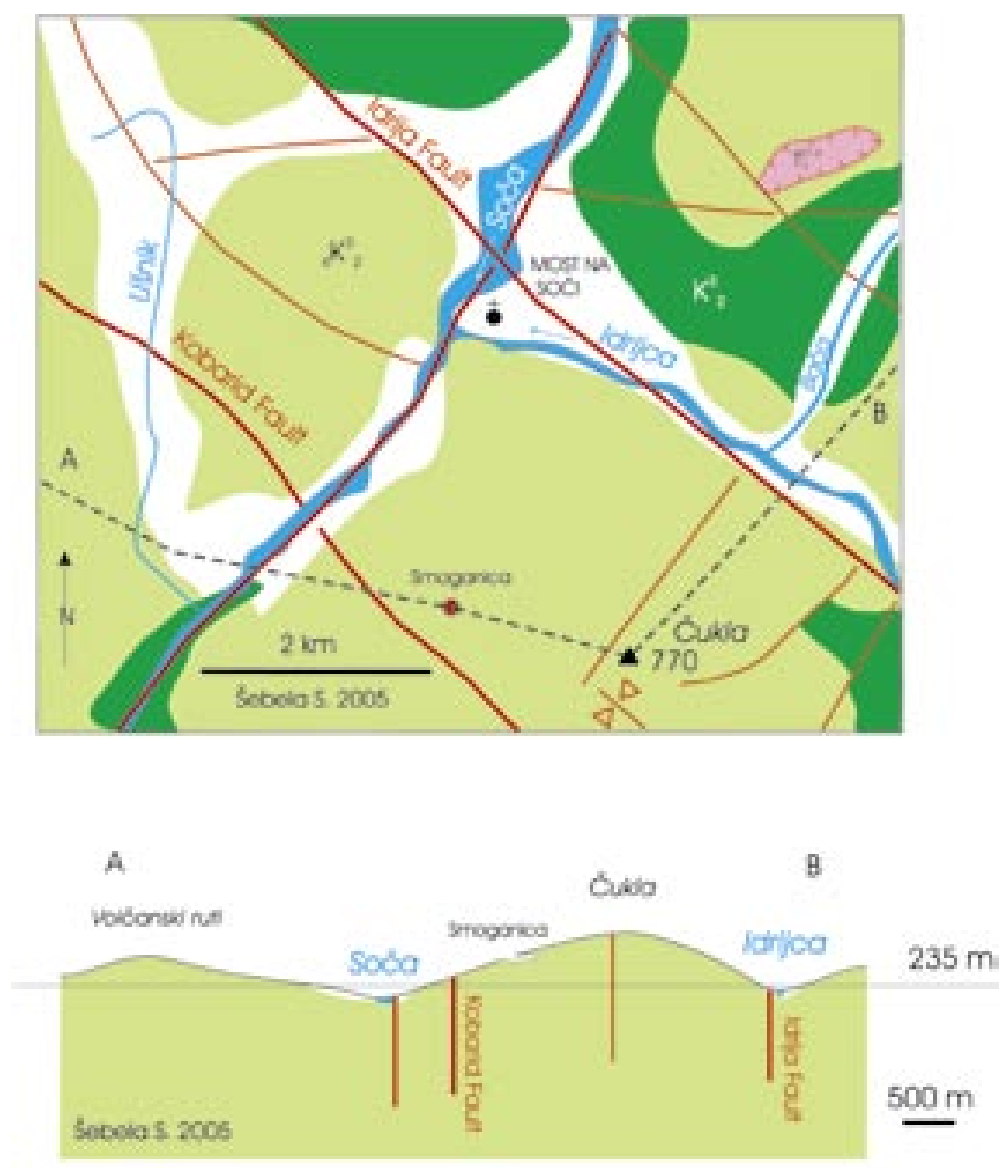

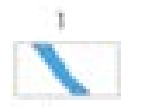

8

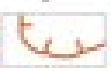

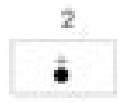

9

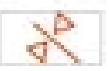

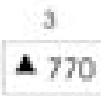

10

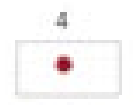

11

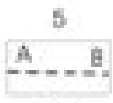

12

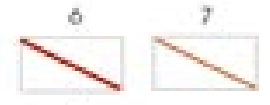

13

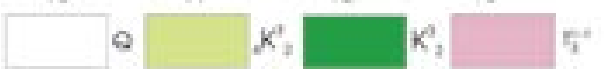

Figure 5: Geology of Smoganica (after Buser, 1986; 1987 and Poljak, 2000).

1-river, 2-town, 3-hill, 4-Smoganica cave, 5-cross section, 6-stronger fault, 7-fault, 8-thrust, 9syncline, 10-Quaternary sediments (alluvium etc.), 11-Cretaceous flysch (sandstone, marl, breccia) ${ }_{4} K_{2}^{3}$ 12-limestone $K_{2}^{3}$, 13-Triassic carbonate rocks $T^{2+3}{ }_{3}$.

Slika 5: Geologija Smoganice (po Buserju, 1986; 1987 in Poljaku, 2000).

1-reka, 2-mesto, 3-hrib, 4-Smoganica, 5-prečni profil, 6-močnejši prelom, 7-prelom, 8-nariv, 9-sinklinala, 10-kvartarni sedimenti (aluvij itd.), 11-kredni fliš (peščenjak, lapor, breča) ${ }_{4} \mathrm{~K}_{2}^{3}$ 12-apnenec $K_{2}^{3}$, 13-triasne karbonatne kamnine $T_{3}^{2+3}$. 


\section{TECTONIC SITUATION OF SMOGANICA}

Smoganica is situated about $2 \mathrm{~km}$ south from Idrija fault and about $200 \mathrm{~m}$ north from Kobarid fault (Figure 5). The area south of Idrijca and east from Soča is deformed into some smaller anticlines and synclines due to the thrusting from the north. The Upper Cretaceous flysch rocks were very favourable for thrusting deformations. Smoganica is situated 3-4 km south from the thrust border between Southern Alps and Outer Dinarides and is part of Outer Dinarides.

According to Placer's (1999) classification the studied area belongs to Trnovo nappe where we find deeper water sedimentary rocks of Dinaric platform (Upper Cretaceous and Paleocene). Trnovo nappe is overthrusted from NE to SW on the Hrušica nappe. The Southern Alps are overthrusted from north southwards on the Trnovo nappe along the Southalpine front. More preciselly Tolmin nappe is overthrusted to Trnovo nappe (Placer 1999).

The Dinaric nappes are connected with the genesis of Eocene flysch beds, which would mean that the cycle of this overthrusting terminated most likely at the end of the Eocene times. The Southalpine nappes lie on the Dinaric nappes, so they could be only younger (Placer 1999).

There are two principal fissure orientations (Figure 2, B) in the cave, N30-45 $\mathrm{E}(29 \%)$ and $\mathrm{N} 120-135^{\circ} \mathrm{E}(19 \%)$. Both directions represent opened fissures filled with calcite mineralization. If the wider class interval is considered most of the fissures $(61 \%)$ are developed between $\mathrm{N} 15-60^{\circ} \mathrm{E}$ what represents cross-dinaric orientation. The Dinaric oriented fissures $\left(\mathrm{N} 105-135^{\circ} \mathrm{E}\right)$ are representing $34 \%$.

In the $\mathrm{W}$ part of the cave the cross Dinaric fissures (NE-SW) are cut by Dinaric (NW-SE) ori-

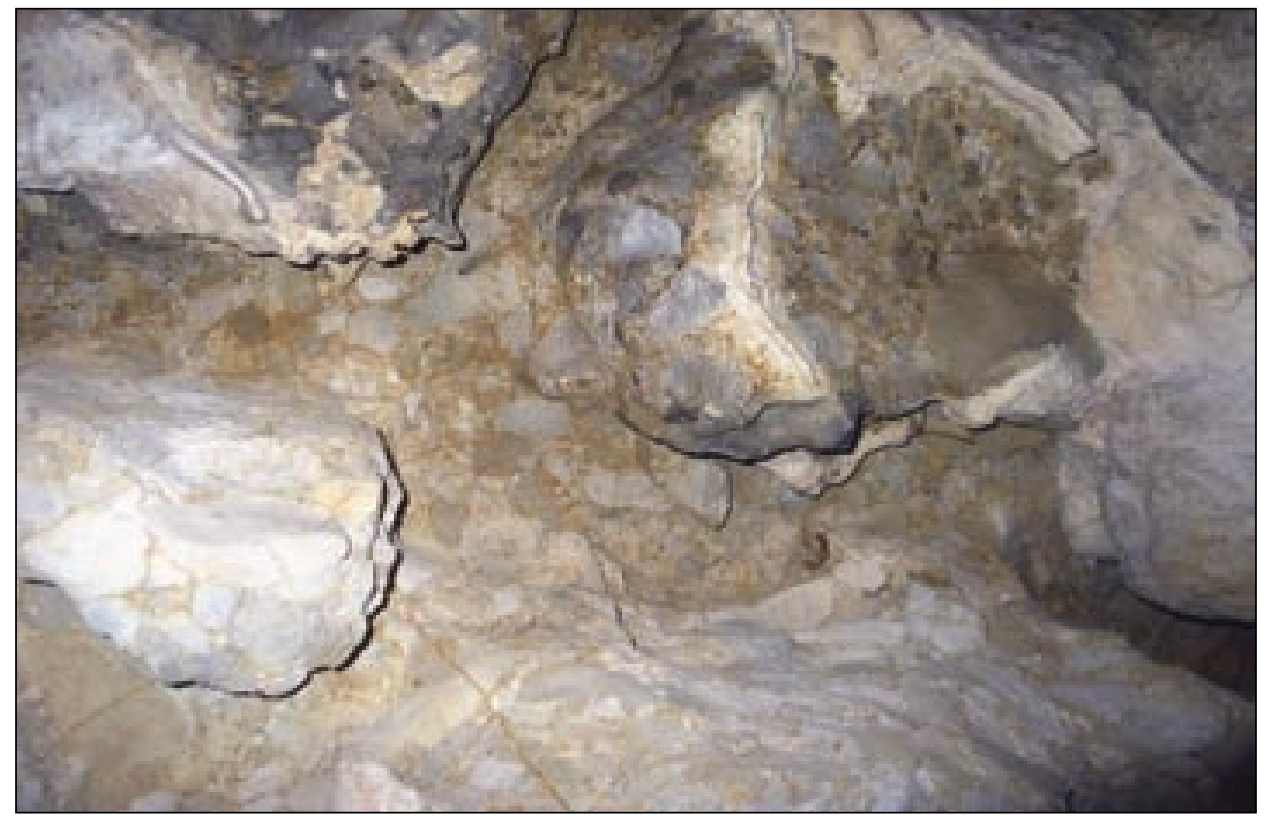

Figure 6: The above-sediment rock forms on the ceiling (photo by T. Slabe).

Slika 6: Nadnaplavinske skalne oblike na stropu (foto T. Slabe). 
ented fissures. In the middle part of the cave, just before the low passages arise the Dinaric oriented fissure is cut by cross Dinaric one.

The rose diagram (Figure 2, A) of passage orientation (class interval $15^{\circ}$ ) demonstrates that the most passages $(38,4 \%)$ are oriented in the $\mathrm{N} 120-135^{\circ} \mathrm{E}$. The direction $\mathrm{N} 115-120^{\circ} \mathrm{E}(17,5 \%)$ represents the second orientation and the direction $\mathrm{N} 30-45^{\circ} \mathrm{E}(16 \%)$ the third. The passages of Smoganica are mostly developed in Dinaric orientation (NW-SE).

The bedding planes have mostly Dinaric orientation that is the result of folding and thrusting in the Neogene. But there are also bedding planes with cross Dinaric orientation, which is the effect of folding in Upper Cretaceous and Paleogene (Buser 1986). In the Smoganica cave part of passages is developed along the contact between higher breccia layers and lower marls. The bedding planes dip towards SW with the dip angle of $5-10^{\circ}\left(250 / 5-10^{\circ}\right.$ and $\left.220 / 10^{\circ}\right)$.

According to Buser (1986) the studied area is part of Outer Dinarides, of the Trnovo nappe particulary.

Most of faults run in Dinaric orientation. They were formed in the Pliocene and were active in the Pleistocene. In that period cross Dinaric faults were formed. Alpine faults (E-W) were formed already in middle Triassic, but were later many times reactivated. Idrija fault is one of the most typical faults along which Cretaceous rocks at Slap ob Idrijci were horizontally displaced for $4 \mathrm{~km}$ (Buser 1986).

Triassic carbonate rocks are part of Podmelec ovethrust (Buser 1986).

The cross Dinaric fault that runs through the valley of the Soča river (Figure 5) was determined by Poljak (2000).

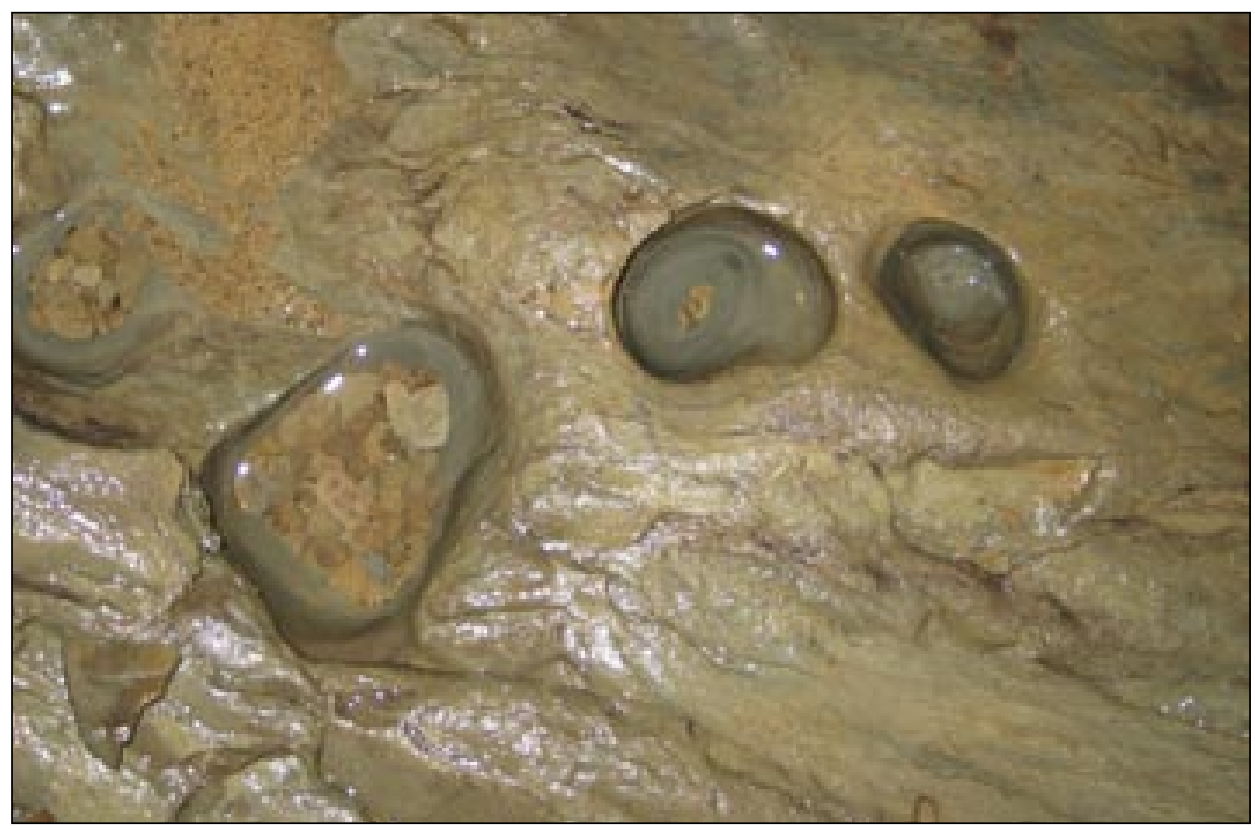

Figure 7: Potholes (photo by T. Slabe).

Slika 7: Draslje (foto T. Slabe). 


\section{CAVE ROCKY RELIEF}

Cave rocky relief is an important trace for the most typical development stages of the Smoganica. In the entrance part of the cave there is a ceiling cupola that is already reshaped by younger effects. The cupola was probably formed in the period when the cave was in phreatic conditions. Abovesediment rock forms are reshaping the ceiling cupola.

There are parts of the cave passages where wall notches are well visible. Those that are formed on the upper part of cave passage cross section are mostly paragenetic in their origin. Crests between wall notches can also be found in some passages in the middle of walls. Such shape of the cave cross section can be the result of selective growth of three-dimensional cave system, lithological properties or vadose undercutting, visible as a keyhole shape of the cave cross section.

The best visible stage of the cave development is paragenetic reshaping of cave passages. In the passages with lower ceilings the above-sediment rock forms can be found (Figure 6). These are the so-called above-sediment ceiling channels, which can take place in the whole upper part of the ceiling. We can also find smaller isolated above-sediment ceiling channels or a group of them - above-sediment anastomoses. In the case of bigger above-sediment ceiling channels the influence of different lithology is not important.

The next stage is reshaping of cave passages with actual water flow. Water is cutting floor channels into the breccia (Figure 4) and marl. Occasional stronger stream is making scallops and potholes (Figure 7). In breccia of Smoganica the scallops are formed only on the clasts of limestone bigger than $20 \mathrm{~cm}$. The scallops are $5 \mathrm{~cm}$ long and have irregular shapes. Scallops $(7 \mathrm{~cm}$ long and

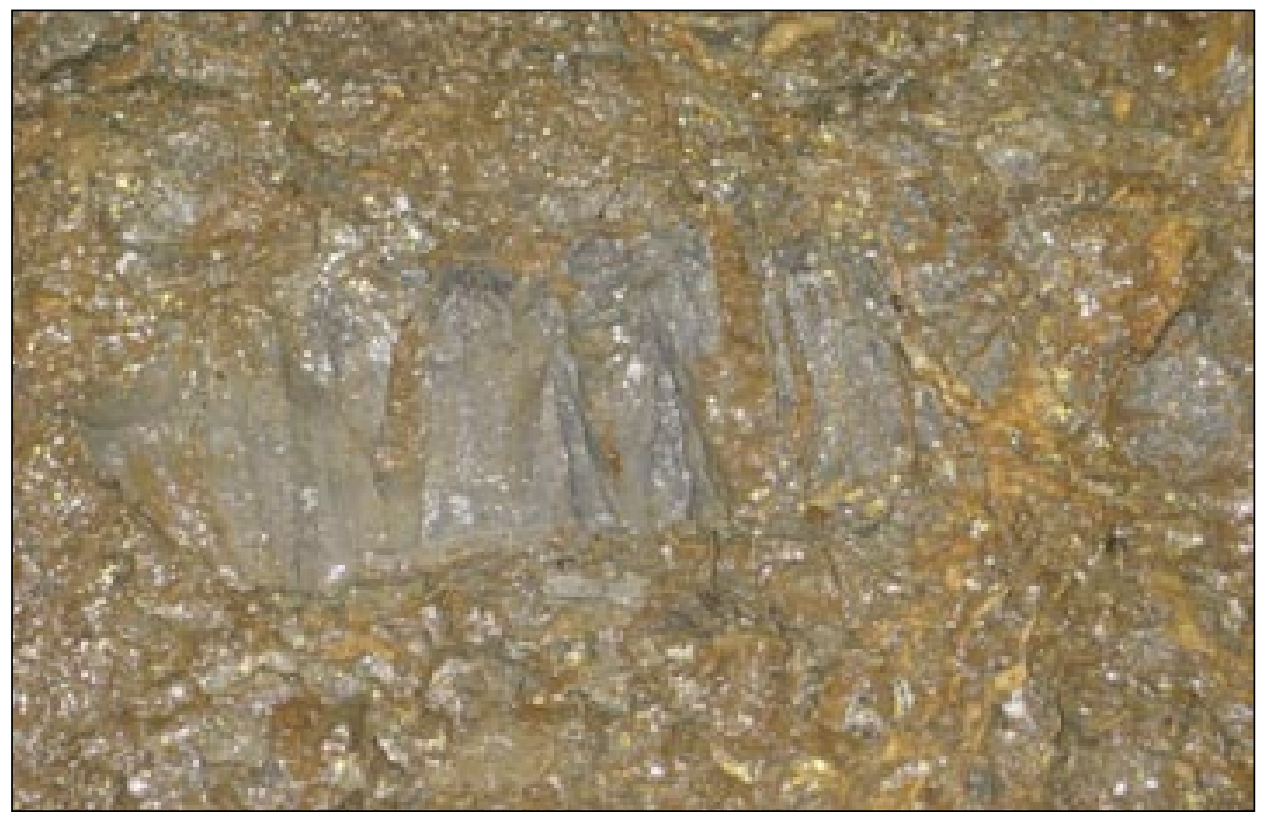

Figure 8: Flutes and channels are formed on bigger limestone clasts (photo by M. Knez). Slika 8: Žlebovi in kanali so se oblikovali na apnenčastih klastih (foto M. Knez). 
$3 \mathrm{~cm}$ wide) are formed also on the marl with calcite cement. Such scallops are typical to be formed below lower water flow conditions. Potholes can reach the diameter up to $30 \mathrm{~cm}$. They are developed also on the marl.

On the walls of cave chimneys and on the cave walls that are formed inside subvertical fissures the rock forms are made due to percolation of water. Stronger water trickles are forming longer, vertical, half-circular channels. Between them there are distinctive crests.

The formation of flutes and channels depends on the rock lithology. Such forms are formed only on more uniform parts of breccia or on bigger limestone clasts (Figure 8).

The formation of small features is connected with the sediment that was brought in the cave by percolating water and deposited on the rough surface with different inclination.

On the gently inclined wall sections between below-sediment cups the pendants are formed. The corrosion of the cave wall below the wet sediment that is caught into the small pits is at first more effective. On the more or less inclined cave walls the small steps are formed. The cave sediment is deposited over more or less horizontal wall sections. The deposited sediment protects them against rapid corrosion. On the cave ceiling small pendants are formed. The sediment is deposited over the pendants and is protecting them against further corrosion. The water that runs on the overhang first corrodes the area between the pendants.

Smoganica is formed from the system of smaller passages that have been developed inside the breccia in 3D. The cave was primarily formed in phreatic conditions. Later it was completely filled with cave sediments. The above-sediment rock forms were developed. Cave sediments were later removed from the cave. Today the active water stream is cutting rock forms in the bottom of the cave passages. Higher water quantities are forming scallops and potholes and lower quantities floor channels. Smoganica can be described as polygenetic cave, because the passages are reshaped by percolated water.

\section{CONCLUSIONS}

Smoganica is developed in $10 \mathrm{~m}$ thick limestone breccia that belongs to the Upper Cretaceous flysch rocks. The cave that is $492 \mathrm{~m}$ long is situated Between Idrija and Kobarid fault $352 \mathrm{~m}$ above the Soča river (Figure 5). Smoganica is a spring cave with branch passages divided into two floors.

The prevailing passage orientation (Figure 2, A) is Dinaric NW-SE. Prevailing fissure orientation (Figure 2, B) is cross Dinaric (NE-SW).

The shape of the Smoganica and the rock relief are showing different conditions in the development. The cave started to develop as a system of passages within the fissured limestone breccia deposited above nonpermeable green marls in the phreatic zone. Later the periods of lowering of the piezometer level appeared. In the first stages the cave was frequently flooded and filled with fine-grained cave sediments. The water flowed over the sediments and heightened the passages. The following stage was the rapid fall of the piezometer water level. Nonpermeable layers within the flysch are the reason for actual water flow in the cave even if the cave is today high up on the slope above the Soča valley. Smaller water flows are cutting the bottoms of lower passages. Through the cave ceiling the water is percolating from the surface and reshaping the passages.

The study was conducted within the programme Karst Research financed by the Slovenian Research Agency. 


\section{REFERENCES}

Arhiv Inštituta za raziskovanje krasa ZRC SAZU, Postojna.

Buser, S., 1986: Tolmač lista Tolmin in Videm. Osnovna geološka karta SFRJ 1:100 000.- Zvezni geološki zavod Beograd, 103 str., Beograd.

Buser, S., 1987: Osnovna geološka karta SFRJ 1:100 000, list Tolmin in Videm.- Zvezni geološki zavod, Beograd.

Habič, P., 1974: Nekatere speleološke značilnosti Trnovskega gozda.- Naše jame 16, 63-78, Ljubljana.

Janež, J., Čar, J., Habič, P. \& Podobnik, R., 1997: Vodno bogastvo Visokega Krasa.- Geologija d.o.o., 167 str., Idrija.

Placer, L., 1999: Prispevek k makrotektonski rajonizaciji mejnega ozemlja med Južnimi Alpami in Zunanjimi Dinaridi.- Geologija 41 (1998), 223-255, Ljubljana.

Poljak, M., 2000: Strukturno-tektonska karta Slovenije, izdelana po podatkih Osnovne geološke karte SFRJ 1:100.000, Mladinska knjiga tiskarna d.d., Ljubljana.

Slabe, T., 1995: Cave Rocky Relief.- Založba ZRC, 10, 128 pp., Ljubljana. 


\section{SMOGANICA - JAMA RAZVITA V ZGORNJEKREDNI BREČI}

\section{Povzetek}

Na planoti Banjšic (SZ Slovenija) je najdaljša izvirna jama 492 m dolga Smoganica (Jama pod Smoganico, kat.št. 823). Jama (505 m nadmorske višine) leži na JZ pobočju, vzhodno od reke Soče (153 m nadmorske višine). Smoganica (Sliki 2 and 3) je razvita v apnenčasti breči debeline $10 \mathrm{~m}$, ki je del zgornje krednega fliša.

Na razdalji okrog 200 m se glavni rov dvigne za 16 m, ozki in nizki rovi pa globlje v notranjost niso prehodni. Jama ima precej kaminov in redke kapnike. Izoblikovani sta dve etaži, v spodnji je danes voda (Slika 4). Po Habiču (1974) so višji suhi rovi starejši in deloma že preoblikovani s podori, vendar v obeh etažah še prevladujejo erozijske in korozijske oblike. Slabe (1995) je Smoganico opisal kot poligenetsko jamo. Janež s sodelavci (1997) poudarja, da je drevesasto razvejan tloris rezultat stekanja vode po razpokah karbonatne kamnine, ki je v okrog 10 m debeli plasti vložena med flišne laporje in peščenjake.

Podobne vendar krajše izvirne jame so pri Bolterjevem zdencu ob Avščku, pri Ajbci nad Logom pri Bodrežu in pri Murniku blizu Drage na Banjšicah. Vse so nastale v konglomeratih med flišem in leže razmeroma visoko v strmih obrobjih flišnih Banjšic (Janež et al. 1997).

V Sloveniji močno prevladujejo kraške jame razvite $v$ apnencih. V manjši meri najdemo jame tudi $\mathrm{v}$ dolomitih, konglomeratih in brečah. Prav zato je nastanek in razvoj Smoganice v zgornjekrednih brečah znotraj flišnih kamnin toliko bolj zanimiv.

Apnenčasto brečo (Slika 3) sestavljajo predvsem kosi krednih in jurskih apnencev. Triasnih apnencev v breči ni bilo najdenih. Klasti so precej povezani, tako da na prepereli površini breče pogosto dobimo videz apnenca. Največkrat je vezivo breče zdrobljen apnenec, redkeje kalcit ali lapor. Pri debelejših plasteh breče je vezivo karbonatno, pri tanjših prevladuje lapornato vezivo. Klasti se močno stikajo, tako da je veziva relativno malo. Pogosto posamezni apnenčevi kosi ali bloki "plavajo" v flišnem laporju. Pod brečastimi vložki so flišne plasti nagubane zaradi polzenja trdnih apnenčevih blokov preko še ne docela strjenih flišnih plasti. Odvodni plazovi, ki so prinašali apnenčev material za nastanek breče, so odtrgali z dna pogosto tudi flišne plasti in jih valili s seboj ter zgnetli in nagubali. Tako so tudi ponekod v breči nepravilni večji vključki fliša, ki je drobno naguban. Starost breče je bila dokazana predvsem z makro fosili: rudisti in koralami.

Plasti laporja so različno debele; od metra do več deset metrov. Kjer so plasti tanjše sledimo postopnemu prehodu iz breče v lapor. V laporju so pogosto apnenčevi kosi. Barva laporja variira od zelene do rdeče. V bistvu je lapor flišni sediment, ker pa med plastmi laporja skoraj ni plasti peščenjaka ali kalkarenita, je na geološki karti (Buser, 1987) izdvojen kot posebni različek. Pogosto je lapor masiven, zato se tam iverasto kroji. Vpad lahko določime le tam, kjer so med laporjem tanjše plasti peščenjaka, kalkarenita ali apnenčeve breče. Starost laporja nekarbonatnih plasti je bila določena z mikrofosili, od katerih so najpogostejše globotrunkane in nanoplankton, ponekod tudi školjke.

Kjer so v flišnih plasteh tudi plasti peščenjaka, so le-te debele od nekaj cm do enega metra. Peščenjaki vedno vsebujejo sljudo. V plasteh lahko opazimo postopno zrnavost, vzporedno laminacijo in drugo. Tokovnih sledi na spodnjih straneh peščenjakovih plasti je malo.

V Smoganici poteka del rovov po slemenitvi plasti breče, ki je v kontaktu s spodaj ležečim laporjem. Vpad plasti je proti JZ, vpadni kot je $5-10^{\circ}\left(250 / 5-10^{\circ}\right.$ in $\left.220 / 10^{\circ}\right)$.

Po podatkih Buserja (1986) je v tektonskem smislu raziskani teren del Zunanjih Dinaridov in 
sicer Trnovskega pokrova. Smoganica leži okrog 2 km južno od Idrijskega preloma in okrog $200 \mathrm{~m}$ severno od Kobariškega preloma (Slika 5). V Smoganici prevladujeta 2 smeri razpok (Slika 2, B), to sta $\mathrm{S} 30-45^{\circ} \mathrm{V}(29 \%)$ in $\mathrm{S} 120-135^{\circ} \mathrm{V}(19 \%)$. Obe smeri predstavljata odprte razpoke zapolnjene s kalcitom. Če upoštevamo širši interval, potem je največ razpok (61 \%) razvitih v smeri S15-60V, kar predstavlja prečno dinarsko smer. Razpoke v dinarski smeri $\left(\mathrm{S} 105-135^{\circ} \mathrm{V}\right)$ predstavljajo $34 \%$.

V zahodnem delu Smoganice dinarsko usmerjene razpoke sekajo prečno dinarske. V osrednjem delu jame, tik preden se rovi znižajo, dinarsko razpoko seka prečno dinarska.

Rozeta (Slika 2, A) smeri rovov (interval $\left.15^{\circ}\right)$ prikazuje, da je največ $(38,4 \%$ ) rovov v smeri S120-135 V. Smer S115-120 V (17,5\%) predstavlja drugo najbolj zastopano smer, smer rovov $\mathrm{S} 30-45^{\circ} \mathrm{V}(16 \%)$ pa tretjo. Večina rovov Smoganice je razvita v dinarski smeri, večina razpok pa $\mathrm{v}$ prečno dinarski in dinarski smeri.

Jamski skalni relief razkriva nekaj značilnih obdobij razvoja jame. V vzhodnem delu jame je stropna kupola, ki je v dobršni meri že preoblikovana z mlajšimi dejavniki, zato je težko opredeliti njeno poreklo. Če jo je oblikoval vodni tok, seveda priča o oblikovanju jame, ko so bili njeni rovi še zaliti.To predpostavko krepijo nadnaplavinske skalne oblike, ki jo členijo, so torej mlajše od nje. Posamezne rove členijo izrazite stenske zajede. Tiste na zgornjem delu oboda so večinoma paragenetske, razi med zajedami pa potekajo tudi po sredini sten.

Eno najbolj značilnih obdobij razvoja jame, ki ga lahko razberemo iz skalnega reliefa, je njeno paragenetsko preoblikovanje. Nadnaplavinskim skalnim oblikam (Slika 6) lahko sledimo na nižjih stropih, torej če niso bili mlajše preoblikovani z vodo, ki ob razpokah prenika s površja v večini rovov. To so nadnaplavinski stropni žlebovi, ki lahko zavzemajo celoten del oboda rova, posamezni se vijejo po stropu obsežnejših rovov ali pa so povezani v splet, ki ga označujemo kot nadnaplavinske anastomoze.

Sledi obdobje preoblikovanja rovov z vodnim tokom, ki se pretaka po skalnih tleh. Voda vrezuje talne žlebove v brečo in peščenjak. Občasni večji vodni tok pa dolbe fasete in draslje (Slika 7).

$\mathrm{Na}$ stenah kaminov, ki sekajo jamske rove in na stenah rovov, ki se oblikujejo ob izrazitih pokončnih razpokah, so značilne sledi polzenja vode. Voda združena v večje curke dolbe večje, navpične in polkrožne žlebove (Slika 8). Na nastanek in oblikovanje žlebičev, ki členijo stene rovov in tudi žlebove, pa pomembno vpliva tudi sestava kamnine, po kateri polzi voda.

Današnja jama je nastala iz spleta manjših rovov, ki so trodimenzionalno votlili karbonatne plasti. Kot kaže so prevladujoče vodne poti ob povečanju izbranih rovov preraščale tudi manjše rove v bližini. Jama je nastala $\mathrm{v}$ zaliti coni, o čemer priča stropna kupola. Jama je bila v določenem obdobju popolnoma in dolgotrajno zapolnjena $\mathrm{z}$ drobnozrnato naplavino. Nad njo se je $\mathrm{v}$ zaliti coni pretakala voda in izdolbla nadnaplavinske skalne oblike. Voda je naplavino sprala iz jame. Vodne rove danes oblikuje vodni tok, ki se pretaka po skalnih tleh. Jama je obisela na pobočju doline Soče, ohranjajo jo neprepustne plasti, ki so pod karbonatnimi.

Jamo lahko opredelimo kot poligenetsko, saj je njene dele že povsem preoblikovala voda, ki prenika s površja in polzi po jamskih stenah. 